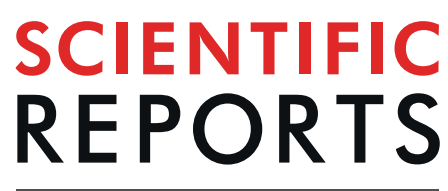

natureresearch

Check for updates

\title{
OPEN Iridium Corroles Exhibit Weak Near- Infrared Phosphorescence but Efficiently Sensitize Singlet Oxygen Formation
}

\author{
Ivar K. Thomassen ${ }^{1}$, Laura J. McCormick-MPherson ${ }^{2}$, Sergey M. Borisov ${ }^{3 凶}$ \& Abhik Ghosh $^{1 凶}$
}

Six-coordinate iridium(III) triarylcorrole derivatives, $\operatorname{Ir}[T p X P C)] \mathrm{L}_{2}$, where $\mathrm{T} p \mathrm{XPC}=\operatorname{tris}($ para-X-phenyl) corrole $\left(X=\mathrm{CF}_{3}, \mathrm{H}, \mathrm{Me}\right.$, and $\left.\mathrm{OCH}_{3}\right)$ and $\mathrm{L}=$ pyridine (py), trimethylamine (tma), isoquinoline (isoq), 4-dimethylaminopyridine (dmap), and 4-picolinic acid (4pa), have been examined, with a view to identifying axial ligands most conducive to near-infrared phosphorescence. Disappointingly, the phosphorescence quantum yield invariably turned out to be very low, about $0.02-0.04 \%$ at ambient temperature, with about a two-fold increase at $77 \mathrm{~K}$. Phosphorescence decay times were found to be around $\sim 5 \mu$ at $295 \mathrm{~K}$ and $\sim 10 \mu$ s at $77 \mathrm{~K}$. Fortunately, two of the $\left.\operatorname{Ir}\left[T p \mathrm{CF}_{3} \mathrm{PC}\right)\right] \mathrm{L}_{2}$ derivatives, which were tested for their ability to sensitize singlet oxygen formation, were found to do so efficiently with quantum yields $\Phi\left({ }^{1} \mathrm{O}_{2}\right)=0.71$ and 0.38 for $\mathrm{L}=$ py and $4 \mathrm{pa}$, respectively. Iridium corroles thus may hold promise as photosensitizers in photodynamic therapy (PDT). The possibility of varying the axial ligand and of attaching biotargeting groups at the axial positions makes iridium corroles particularly exciting as PDT drug candidates.

The $5 \mathrm{~d}$ transition metal corroles represent an unusual class of size-mismatched metal-ligand assemblies, which combine a large $5 \mathrm{~d}$ ion and a sterically constrained, macrocyclic corrole ligand ${ }^{1}$. Although many of the complexes were initially synthesized as part of curiosity-driven exercises, their photophysical properties now promise a wide range of practical applications ${ }^{2,3}$, as near-IR emitters, as oxygen sensors, and as photosensitizers for photodynamic therapy, dye-sensitized solar cells, and triplet-triplet annihilation upconversion ${ }^{4-9}$. Iridium corroles were among the first $5 \mathrm{~d}$ metallocorroles to be synthesized ${ }^{10}$ and reported as exhibiting as near-IR phosphorescence at room temperature ${ }^{4,5}$. Subsequently, $\mathrm{Au}^{11-14}, \mathrm{OsN}^{15}, \mathrm{ReO}^{16}$, and $\mathrm{Pt}^{17}$ corroles were synthesized and found to exhibit significantly stronger phosphorescence ${ }^{6-9}$. In this reexamination of six-coordinate Ir corroles (structures depicted below), we attempted to determine whether different axial ligands, including pyridine (py), trimethylamine (tma), isoquinoline (isoq), 4-dimethylaminopyridine (dmap), and 4-picolinic acid (4pa), might be exploited to enhance the phosphorescent behavior.

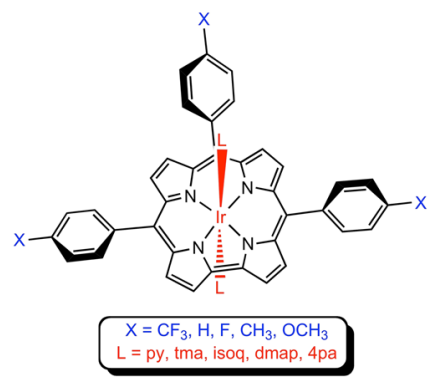

${ }^{1}$ Department of Chemistry, UiT -The Arctic University of Norway, N-9037, Tromsø, Norway. ${ }^{2}$ Advanced Light Source, Lawrence Berkeley National Laboratory, Berkeley, California, 94720-8229, United States. ${ }^{3}$ Institute of Analytical Chemistry and Food Chemistry, Graz University of Technology, Stremayrgasse 9, 8010, Graz, Austria. ${ }_{\text {e-mail: }}$ sergey.borisov@tugraz.at; abhik.ghosh@uit.no 

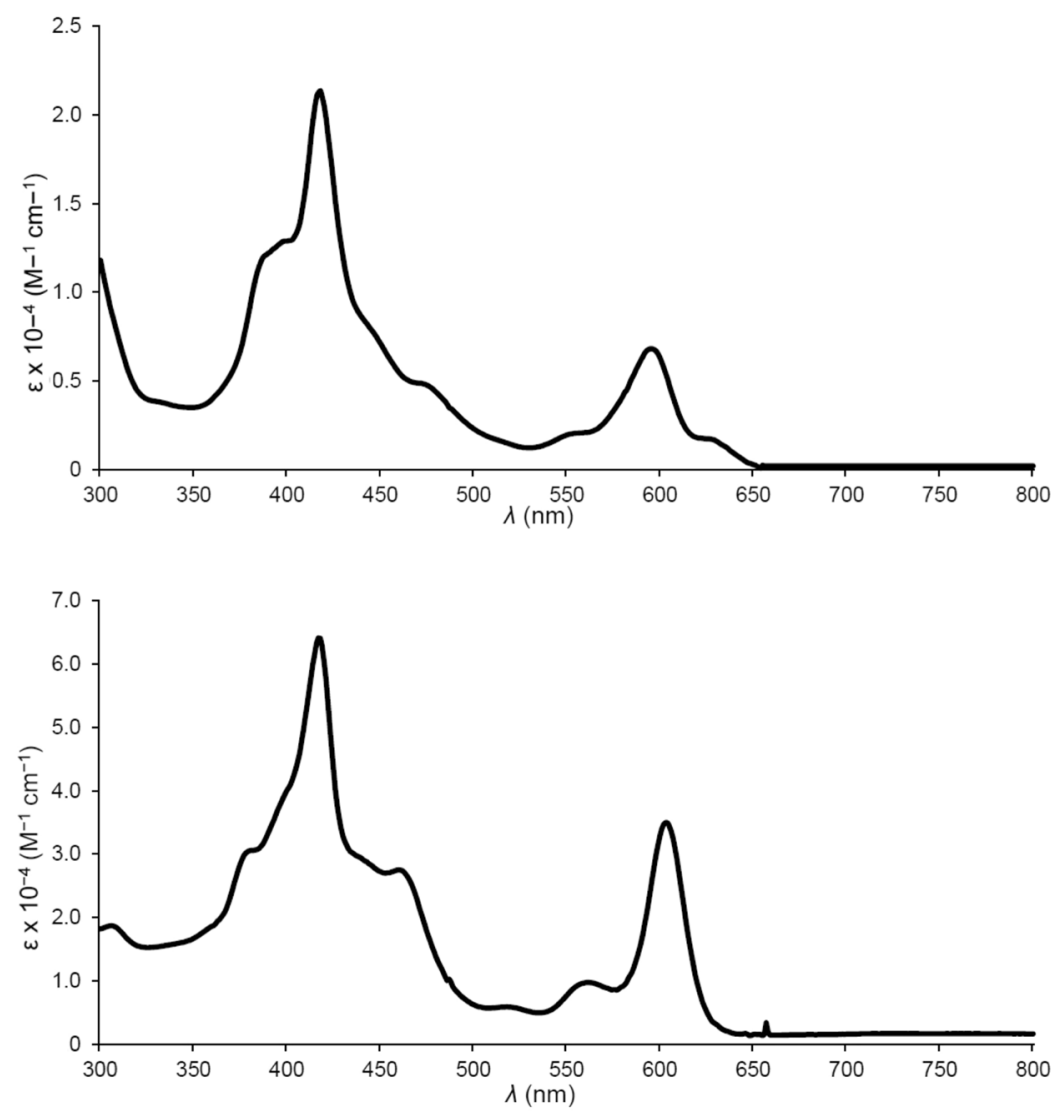

Figure 1. Representative UV-vis spectra in dichloromethane: $\operatorname{Ir}[(\mathrm{T} p \mathrm{MePC})] \operatorname{tma}_{2}$ (top) and $\operatorname{Ir}[(\mathrm{T} p \mathrm{MePC})] \mathrm{py}{ }_{2}$ (bottom).

\begin{tabular}{|c|c|c|c|c|c|}
\hline Complex & B & Q & $E_{1 / 20 x 1}$ & $E_{1 / 20 \times 2}$ & $E_{1 / 2 \text { red1 }}$ \\
\hline $\operatorname{Ir}[\mathrm{TPC}] \mathrm{tma}_{2}$ & $384,416^{*}, 468$ & $596^{*}$ & 0.31 & 1.09 & - \\
\hline $\operatorname{Ir}[\mathrm{TPC}] \mathrm{py}_{2}$ & $414^{*}, 459$ & $562,602^{*}$ & 0.28 & 1.00 & - \\
\hline $\mathrm{Ir}[\mathrm{T} p \mathrm{MePC}] \mathrm{tma}_{2}$ & $384,417^{*}, 468$ & $598^{*}$ & 0.26 & 1.02 & - \\
\hline $\operatorname{Ir}[\mathrm{T} p \mathrm{MePC}] \mathrm{py}_{2}$ & $417^{*}, 460$ & $562,603^{*}$ & 0.52 & 1.02 & - \\
\hline $\mathrm{Ir}[\mathrm{T} p \mathrm{OMePC}] \mathrm{tma}_{2}$ & $384,417^{*}, 468$ & $600^{*}$ & 0.23 & 0.94 & - \\
\hline $\mathrm{Ir}[\mathrm{T} p \mathrm{OMePC}] \mathrm{py}_{2}$ & $416^{*}, 458$ & $563,605^{*}$ & 0.20 & 0.89 & - \\
\hline $\mathrm{Ir}\left[\mathrm{T} p \mathrm{CF}_{3} \mathrm{PC}\right] \mathrm{tma}_{2}$ & $418^{*}$ & $595^{*}$ & 0.44 & 1.18 & - \\
\hline $\operatorname{Ir}\left[\mathrm{T} p \mathrm{CF}_{3} \mathrm{PC}\right] \mathrm{py}_{2}$ & $416^{*}$ & $602^{*}$ & 0.41 & 1.11 & -1.71 \\
\hline $\operatorname{Ir}\left[\mathrm{T} p \mathrm{CF}_{3} \mathrm{PC}\right] \mathrm{dmap}_{2}$ & $418^{*}$ & $606^{*}$ & - & - & - \\
\hline $\operatorname{Ir}\left[\mathrm{T} p \mathrm{CF}_{3} \mathrm{PC}\right] 4 \mathrm{pa}_{2}$ & $414^{*}$ & $602^{*}$ & - & - & - \\
\hline $\operatorname{Ir}\left[\mathrm{T} p \mathrm{CF}_{3} \mathrm{PC}\right]$ isoq $_{2}$ & $417^{*}$ & $603^{*}$ & - & - & - \\
\hline
\end{tabular}

Table 1. Absorption maxima $(\lambda, \mathrm{nm})$ and redox potentials (V vs. SCE) for $\operatorname{Ir}(\mathrm{III})$ corroles in dichloromethane $\mathrm{e}^{\mathrm{a}}$. ${ }^{a}$ Asterisks indicate the most intense peaks in the Soret and $\mathrm{Q}$ regions.

\section{Results and Discussion}

Early spectroscopic and structural studies. Four different meso-tris(para-X-phenyl)corrole ligands, $\mathrm{H}_{3}[\mathrm{~T} p \mathrm{XPC}]\left(\mathrm{X}=\mathrm{CF}_{3}, \mathrm{H}, \mathrm{Me}\right.$, and $\left.\mathrm{OMe}\right)$, and two different axial ligands, pyridine (py) and trimethylamine (tma), were initially investigated. The compounds were all found to exhibit broad, asymmetric Soret bands with a maximum at $416 \pm 2 \mathrm{~nm}$ and intense $Q$ bands with the maximum varying over $600 \pm 5 \mathrm{~nm}$ (Fig. 1 and Table 1). Three of the complexes - Ir[TPC] tma $\mathrm{ta}_{2}, \operatorname{Ir}[\mathrm{T} p \mathrm{MePC}] \mathrm{tma}_{2}$, and $\operatorname{Ir}\left[\mathrm{T} p \mathrm{CF}_{3} \mathrm{PC}\right] \mathrm{py} y_{2}$ (Fig. 2, Table 2) - could be structurally characterized, revealing planar metallocorrole macrocycles with Ir- $\mathrm{N}_{\text {corrole }}$ distances of 1.95-1.97 $\AA$ and Ir- $\mathrm{N}_{\text {axial }}$ distances of 2.17-2.18 $\AA$. Electrochemical studies revealed two reversible oxidation potentials, including a rather low first oxidation potential that ranged from 0.2 to $0.44 \mathrm{~V}$ vs. the saturated calomel electrode (Table 1 ). In general, a reduction potential could not be observed within the available potential window for the solvent (dichloromethane), except for $\operatorname{Ir}\left[\mathrm{T} p \mathrm{CF}_{3} \mathrm{PC}\right] \mathrm{py}_{2}$, which showed a reduction potential of $-1.71 \mathrm{~V}$, a reflection of the highly electron-rich character of the macrocycle in Ir corroles (Table 1). All these properties are qualitatively consistent with those observed for Ir tris(pentafluorophenyl)corrole derivatives ${ }^{10}$. 


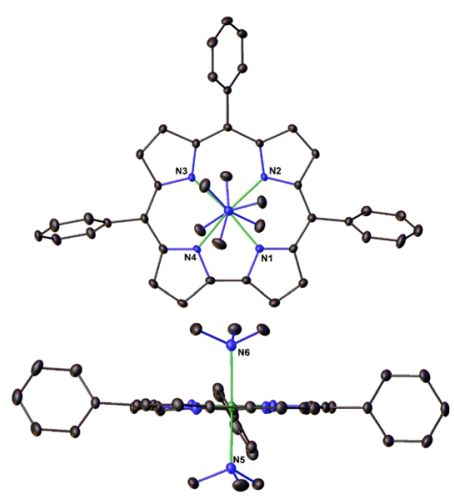

$\operatorname{lr}[\mathrm{TPC}] \mathrm{tma}_{2}$

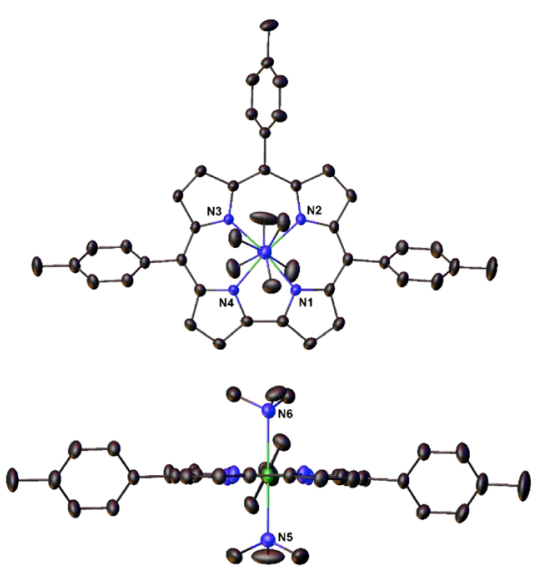

$\operatorname{lr}[\mathrm{TpMePC}] \mathrm{tma}_{2}$

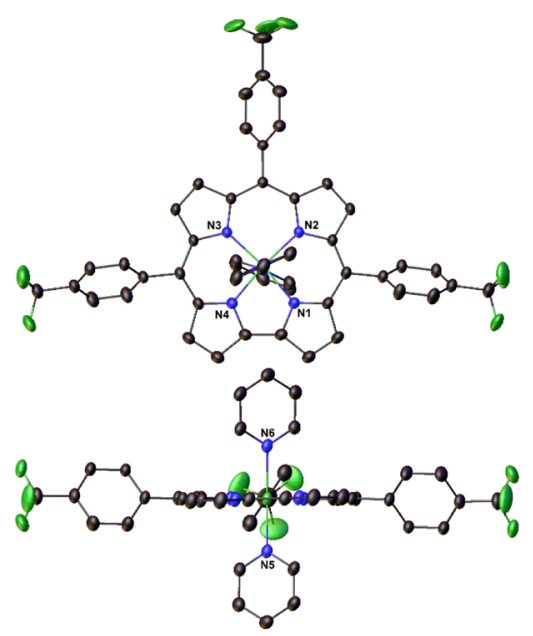

$\operatorname{Ir}\left[\mathrm{TpCF}_{3} \mathrm{PC}\right] \mathrm{py} \mathrm{y}_{2}$

Figure 2. X-ray structures (top and side views) of $\operatorname{Ir}[\mathrm{TPC}] \mathrm{tma}_{2}$ (left), $\operatorname{Ir}[\mathrm{T} p \mathrm{MePC}] \mathrm{tma}_{2}$ (middle), and $\operatorname{Ir}\left[\mathrm{T} p \mathrm{CF}_{3} \mathrm{PC}\right] \mathrm{py}_{2}$ (right). Bond distances ( $\left.\mathrm{A}\right)$ for Ir[TPC]tma 2 : Ir-N1 1.9543(16), Ir-N2 1.9728(16), Ir-N3 1.9745(16), Ir-N4 1.9489(17), Ir-N5 2.1795(18), Ir-N6 2.1672(18). Bond distances ( $\mathrm{A})$ for Ir[TpMePC] tma $_{2}$. Ir-N1 1.953(2), Ir-N2 1.9746(19), Ir-N3 1.978(2), Ir-N4 1.948(2), Ir-N5 2.178(3), Ir-N6 2.176(3). Bond distances $(\AA)$ for $\operatorname{Ir}\left[\mathrm{T}_{p} \mathrm{CF}_{3} \mathrm{PC}\right] \mathrm{py} \mathrm{y}_{2}$ : Ir-N1 1.946(2), Ir-N2 1.9702(18), Ir-N5 2.055(2); note that N5 and N6 are crystallographically equivalent, as are $\mathrm{N} 2$ and $\mathrm{N} 3$, and $\mathrm{N} 1$ and $\mathrm{N} 4$.

\begin{tabular}{|c|c|c|c|}
\hline Compound & $\mathrm{Ir}^{\mathrm{III}}[\mathrm{TPC}] \mathbf{t m a}_{2}$ & IrIIIT $p$ MePC] tma $_{2}$ & $\mathrm{Ir}^{\mathrm{III}}\left[\mathrm{T} p \mathrm{CF}_{3} \mathrm{PC}\right] \mathrm{py}_{2}$ \\
\hline Chemical formula & $\mathrm{C}_{43} \mathrm{H}_{41} \mathrm{IrN}_{6}$ & $\mathrm{C}_{54,25} \mathrm{H}_{66.25} \mathrm{IrN}_{6}$ & $\mathrm{C}_{50} \mathrm{H}_{30} \mathrm{~F}_{9} \mathrm{IrN}_{6}$ \\
\hline Formula mass & 834.02 & 994.58 & 1078.00 \\
\hline Crystal system & Monoclinic & Monoclinic & Monoclinic \\
\hline Space group & $P 2_{1} / n$ & $P 2_{1} / n$ & $C 2 / c$ \\
\hline$\lambda[\AA]$ & 0.7749 & 0.7293 & 0.7749 \\
\hline$a[\AA ̊]$ & $11.4814(5)$ & $12.8383(7)$ & $18.1543(9)$ \\
\hline$b[\AA ̊]$ & $21.7131(10)$ & $15.3802(8)$ & $16.8434(7)$ \\
\hline$c[\AA ̊]$ & $13.7137(6)$ & $24.6017(13)$ & $14.2251(7)$ \\
\hline$\alpha\left[^{\circ}\right]$ & 90 & 90 & 90 \\
\hline$\beta\left[^{\circ}\right]$ & 94.371(2) & $92.934(2)$ & $112.321(2)$ \\
\hline$\Upsilon\left[^{\circ}\right]$ & 90 & 90 & 90 \\
\hline$Z$ & 4 & 4 & 4 \\
\hline $\mathrm{V}[\AA]$ & $3408.8(3)$ & $4851.4(4)$ & $4023.8(3)$ \\
\hline Temperature [K] & $100(2)$ & $150(2)$ & $100(2)$ \\
\hline Density $\left[\mathrm{g} \mathrm{cm}^{-3}\right]$ & 1.625 & 1.362 & 1.779 \\
\hline Meas. reflections & 46872 & 91185 & 40581 \\
\hline Unique reflections & 10433 & 16047 & 10326 \\
\hline Parameters & 457 & 612 & 324 \\
\hline Restraints & 0 & 52 & 6 \\
\hline$R_{\text {int }}$ & 0.0478 & 0.0599 & 0.0431 \\
\hline$\theta$ range $\left[^{\circ}\right]$ & $1.919-33.659$ & $1.603-32.374$ & $1.867-41.256$ \\
\hline$R_{1}, w R_{2}$ all data & $0.0276,0.0551$ & $0.0407,0.1113$ & $0.0463,0.0935$ \\
\hline$S($ GooF) all data & 1.049 & 0.828 & 1.039 \\
\hline Max/min res. dens. [e. $\left.\AA^{-3}{ }^{-3}\right]$ & $1.123 /-1.092$ & $0.903 /-1.735$ & $3.436 /-2.876$ \\
\hline
\end{tabular}

Table 2. Crystallographic data for six-coordinate $\operatorname{Ir}(\mathrm{III})$ corroles.

Near-IR phosphorescence. For the final set of measurements, we chose to focus on the $\mathrm{T}_{p} \mathrm{CF}_{3} \mathrm{PC}$ derivatives but with an expanded set of axial ligands (L) including py, tma, isoquinoline (isoq), 4-dimethylaminopyridine (dmap), and 4-picolinic acid (4pa). All the complexes were found to exhibit weak phosphorescence in the near-infrared part of the spectrum in anoxic solutions (Fig. 3a). The phosphorescence was almost completely quenched in the presence of molecular oxygen. The excitation spectra (Fig. 3b) matched the absorption spectra very well. As expected, the emission spectra were much narrower at $77 \mathrm{~K}$ (Fig. 3c), which enabled more precise determination of the triplet state energies from the edge of the emission spectra. Disappointingly, the 

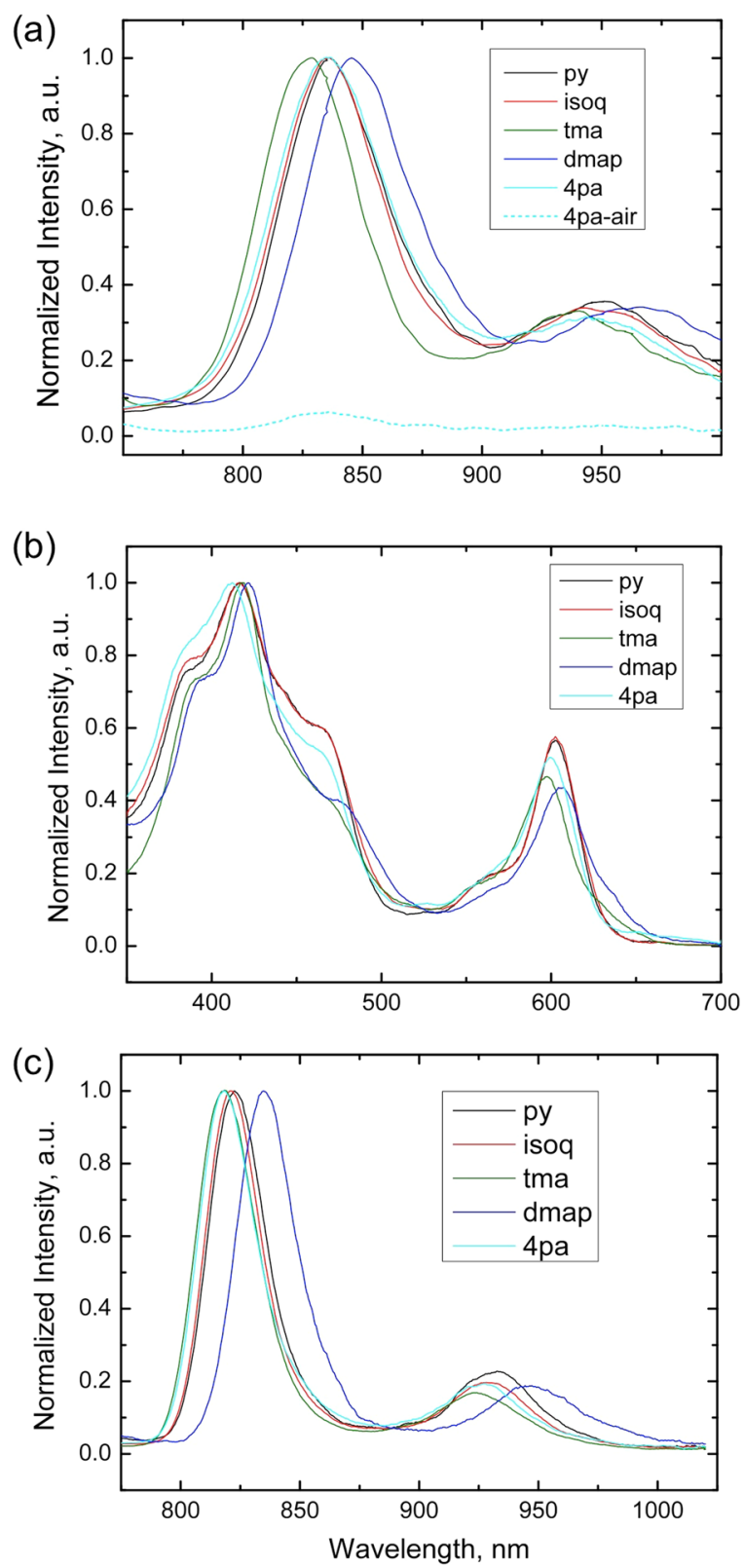

Figure 3. Photophysical properties of $\mathrm{Ir}-\mathrm{T} p \mathrm{CF}_{3} \mathrm{PC}$ complexes with the axial ligands indicated. (a) Emission spectra in anoxic toluene (unless otherwise mentioned) at $295 \mathrm{~K}$ with $\lambda_{\mathrm{ex}}=595-605 \mathrm{~nm}$ (at the maximum of the $\mathrm{Q}$ band). The bis-4pa complex was measured in $\mathrm{EtOH}$ (anoxic conditions - solid line, air-saturated solvent - dashed line). (b) Excitation spectra at $295 \mathrm{~K}$ in the same solvents as in (a). The emission was detected in the maximum of the emission spectra. RG9 long-pass filter was installed in the emission channel to eliminate the monochromator artefacts. (c) Emission spectra in frozen glasses $(77 \mathrm{~K})$ with $\lambda_{\mathrm{ex}}=595-605 \mathrm{~nm}$ (at the maximum of the Q-band). The bis-4pa complex was measured in 4:1 v/v ethanol:methanol, while the other complexes were measured in 2:3 v/v toluene:tetrahydrofuran.

phosphorescence quantum yields for all the complexes turned out to be very low, which made their precise estimation difficult. Quantum yields of around $0.02-0.04 \%$ were estimated at ambient temperature with about a two-fold increase at $77 \mathrm{~K}$. The phosphorescence of the bis-pyridine and bis-isoquinoline complexes was found to be stronger than that of bis-tma and bis-dmap complexes. Furthermore, the emission spectra for the pyridine, isoquinoline, and 4-picolinic acid complexes turned out almost identical (Fig. 3a, Table 3). The decay time profiles for these complexes are mono-exponential (Fig. 4). The fits provide very similar values of $\sim 5 \mu$ s at $295 \mathrm{~K}$ and $\sim 10$ $\mu$ at $77 \mathrm{~K}$. Interestingly, in the case of the bis-dmap complex, a relatively long-decaying component was observed both at ambient temperature and at $77 \mathrm{~K}$.

Singlet oxygen sensitization. Many metalloporphyrins and related compounds are known to be powerful sensitizers of singlet oxygen owing to efficient intersystem crossing and long triplet state lifetimes ${ }^{3-9}$. The fact 


\begin{tabular}{|c|c|c|c|c|c|c|c|}
\hline \multirow[b]{2}{*}{ Complex } & \multicolumn{3}{|l|}{$295 \mathrm{~K}^{\mathrm{a}}$} & \multicolumn{4}{|l|}{$77 \mathrm{~K}^{\mathrm{c}}$} \\
\hline & $\begin{array}{l}\lambda_{\max , \mathrm{em}} \\
(\mathbf{n m})\end{array}$ & $\tau(\mu \mathrm{s})$ & QY (\%) & $\begin{array}{l}\lambda_{\max , \mathrm{em}} \\
(\mathbf{n m})\end{array}$ & $\tau(\mu \mathrm{s})$ & QY (\%) & $\begin{array}{l}\mathrm{E}_{\mathrm{T}}^{\mathrm{e}}, \\
\mathrm{cm}^{-1}\end{array}$ \\
\hline $\left.\operatorname{Ir}\left[\mathrm{T} p \mathrm{CF}_{3} \mathrm{PC}\right)\right] \mathrm{py}_{2}$ & 836 & 5.6 & $\sim 0.04$ & 823 & 9.8 & $\sim 0.04$ & 12560 \\
\hline $\operatorname{Ir}\left[\mathrm{T} p \mathrm{CF}_{3} \mathrm{PC}\right]$ isoq $_{2}$ & 836 & 4.9 & $\sim 0.04$ & 821 & 10.4 & $\sim 0.06$ & 12560 \\
\hline $\operatorname{Ir}\left[\mathrm{T} p \mathrm{CF}_{3} \mathrm{PC}\right] \mathrm{tma}_{2}$ & 828 & $\begin{array}{l}0.6(38 \%) \\
5.1(62 \%)\end{array}$ & $\sim 0.02$ & 818 & 4.2 & $\sim 0.06$ & 12630 \\
\hline $\operatorname{Ir}\left[\mathrm{T} p \mathrm{CF}_{3} \mathrm{PC}\right] \mathrm{dmap}_{2}$ & 846 & $\begin{array}{l}2.3(78 \%) \\
8.1(22 \%)\end{array}$ & $\sim 0.02$ & 835 & $\begin{array}{l}5.2(61 \%) \\
36(39 \%)\end{array}$ & $\sim 0.03$ & 12410 \\
\hline $\operatorname{Ir}\left[\mathrm{T} p \mathrm{CF}_{3} \mathrm{PC}\right] 4 \mathrm{pa}_{2}$ & $836^{\mathrm{b}}$ & $4.8^{\mathrm{b}}$ & $\sim 0.02$ & $818^{\mathrm{d}}$ & $10.7^{\mathrm{d}}$ & $\sim 0.04$ & 12630 \\
\hline
\end{tabular}

Table 3. Photophysical properties of $\left.\operatorname{Ir}\left[\mathrm{T}_{p} \mathrm{CF}_{3} \mathrm{PC}\right)\right] \mathrm{L}_{2}$ derivatives ${ }^{\mathrm{a}-\mathrm{e}} \cdot{ }^{\mathrm{a}}$ In toluene for all complexes except $\operatorname{Ir}\left[\mathrm{T} p \mathrm{CF}_{3} \mathrm{PC}\right] 4 \mathrm{pa}_{2}$. ${ }^{b}$ In ethanol. ${ }^{~}$ In toluene/tetrahydrofuran $(4: 6 \mathrm{v} / \mathrm{v})$ for all complexes except $\operatorname{Ir}\left[\mathrm{T} p \mathrm{CF}_{3} \mathrm{PC}\right] 4 \mathrm{pa}_{2}$. ${ }^{\mathrm{d}}$ In ethanol/methanol $(4: 1 \mathrm{v} / \mathrm{v}){ }^{\mathrm{e}}$ Estimated from the blue edge of the emission spectrum at $77 \mathrm{~K}$.
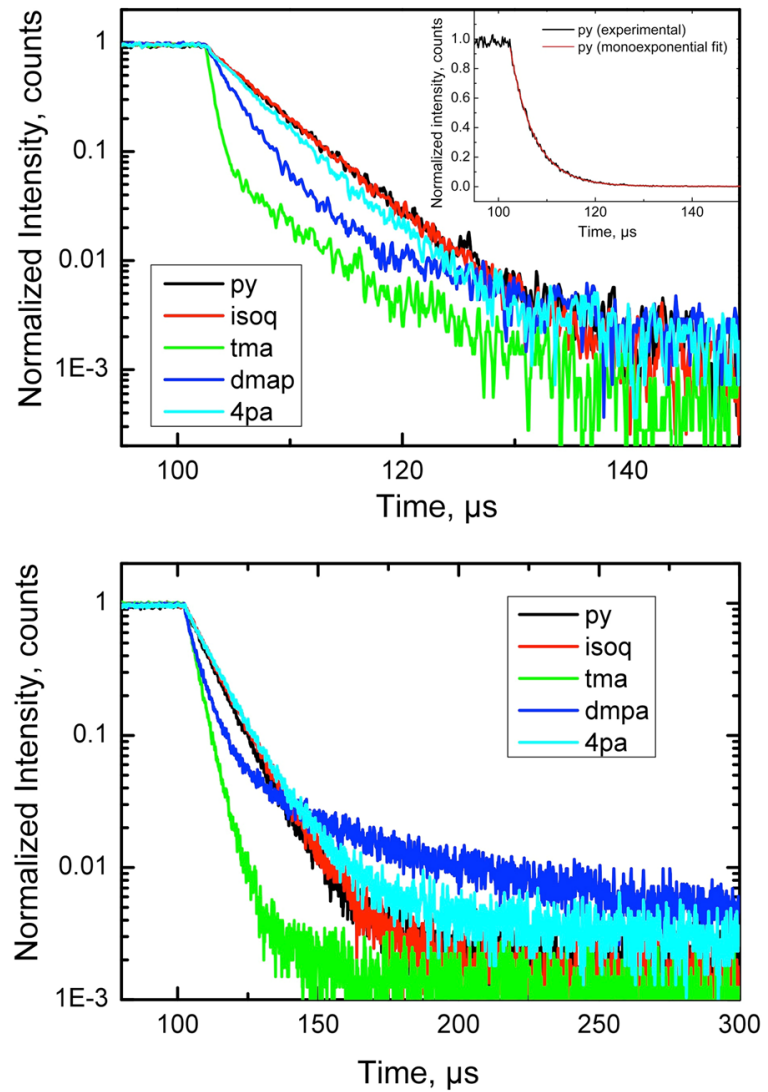

Figure 4. Logarithmic plots for the phosphorescence decay of $\operatorname{Ir}-\mathrm{T}_{p} \mathrm{CF}_{3} \mathrm{PC}$ complexes in anoxic solutions at $295 \mathrm{~K}$ (above) and in frozen glasses at $77 \mathrm{~K}$ (below). The inset depicts the phosphorescence decay of the pyridine complex and the fit according to a monoexponential decay model. The solvents are the same as in Fig. 3.

that Ir corroles exhibit room temperature phosphorescence indicates that the triplet state is populated to at least some degree. In this study, the Ir-TpCF $\mathrm{CF}_{3} \mathrm{PC}$ complexes with py and $4 \mathrm{pa}$ axial ligands were evaluated for their ${ }^{1} \mathrm{O}_{2}$ sensitization capabilities. The assay relied on 9,10-dimethylanthracene as a singlet oxygen acceptor ${ }^{18}$. Methylene blue, which exhibits a quantum yield for ${ }^{1} \mathrm{O}_{2}$ formation $\left[\Phi\left({ }^{1} \mathrm{O}_{2}\right)\right]$ of 0.48 and is spectrally compatible with the corroles, was used as the reference ${ }^{7}$. Fig. 5 shows that $\operatorname{Ir}(\mathrm{III})$ corroles efficiently sensitize the formation of singlet oxygen. In fact, $\Phi\left({ }^{1} \mathrm{O}_{2}\right)$ was found to be 0.71 and 0.38 for $\mathrm{L}=$ py and $4 \mathrm{pa}$, respectively. The lower value for $4 \mathrm{pa}$ correlates with the lower phosphorescence quantum yield for the same complex (Table 3). These $\Phi\left({ }^{1} \mathrm{O}_{2}\right)$ values are several fold higher than those reported for Ir(III) tris(4-cyanophenyl)corrole derivatives, which might reflect more efficient radiationless deactivation of the triplet states of the latter (which exhibit phosphorescence quantum yields of $0.01 \%)^{5}$. Efficient sensitization of ${ }^{1} \mathrm{O}_{2}$ by $\mathrm{Ir}(\mathrm{III})$ complexes is of great interest from the standpoint of photodynamic therapy ${ }^{19-21}$ owing to the co-occurrence of two valuable properties: (i) a long excitation wavelength that enables deeper light penetration and (ii) high flexibility in the choice of axial ligands that should facilitate attachment of tumor markers in the axial positions. Covalent attachment via 4-picolinic acid represents a simple, potential synthetic approach for the latter. 


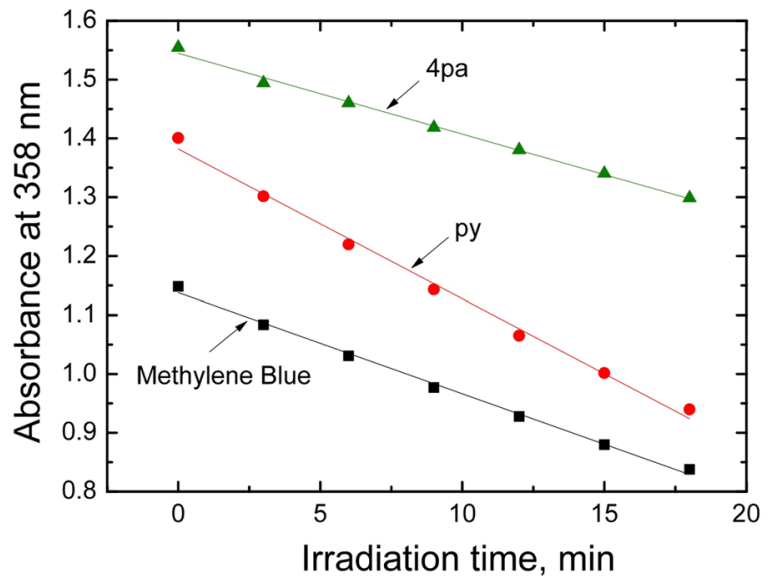

Figure 5. Singlet oxygen-induced degradation of 9,10-dimethylanthracene $(c=0.2 \mathrm{mM})$ as monitored at $358 \mathrm{~nm}$ during photosensitization by two $\left.\operatorname{Ir}\left[\mathrm{T} \mathrm{CF}_{3} \mathrm{PC}\right)\right] \mathrm{L}_{2}$ complexes $(\mathrm{L}=$ py and $4 \mathrm{pa})$ and methylene blue in ethanol. Excitation of the sensitizers was performed at $575 \mathrm{~nm}$.

\section{Conclusion}

Although the photophysical studies of six-coordinate Ir(III) corroles have been previously reported, only a handful of complexes have been examined to date, all exhibiting weak NIR phosphorescence at room temperature. Several additional complexes were accordingly synthesized and examined herein, with a view to identifying axial ligands most conducive to NIR phosphorescence. Unfortunately, regardless of the triarylcorrole and the axial ligands (which varied over pyridine, trimethylamine, isoquinoline, 4-dimethylaminopyridine, and 4-picolinic acid), the phosphorescence quantum yield turned out to be very low, estimated at around $0.02-0.04 \%$ at ambient temperature, with about a two-fold increase at $77 \mathrm{~K}$. Phosphorescence decay times were found to be around $\sim 5 \mu \mathrm{s}$ at $295 \mathrm{~K}$ and $\sim 10 \mu \mathrm{s}$ at $77 \mathrm{~K}$. Fortunately, two of the $\left.\operatorname{Ir}\left[\mathrm{Tp} \mathrm{CF}_{3} \mathrm{PC}\right)\right] \mathrm{L}_{2}$ derivatives were found to efficiently sensitize singlet oxygen formation, with quantum yields $\Phi\left({ }^{1} \mathrm{O}_{2}\right)=0.71$ and 0.38 for $\mathrm{L}=$ py and 4 pa, respectively. Iridium corroles thus may hold promise as photosensitizers in photodynamic therapy. The possibility of varying the axial ligand and of attaching tumor-targeting groups at the axial positions makes iridium corroles particularly exciting as drug candidates.

\section{Experimental Section}

Materials. Unless otherwise mentioned, all chemicals were obtained from Merck. Silica gel $60(0.04-0.063 \mathrm{~mm}$ particle size, 230-400 mesh) was employed for flash chromatography. Silica gel 60 preparative thin-layer chromatographic plates $(20 \mathrm{~cm} \times 20 \mathrm{~cm}, 0.5 \mathrm{~mm}$ thick, Merck) and aluminum oxide 60 preparative thin-layer chromatographic plates $(20 \mathrm{~cm} \times 20 \mathrm{~cm}, 1.5 \mathrm{~mm}$ thick, Merck) were used for final purification of all complexes. Free-base corroles were prepared according to previously reported procedures ${ }^{22,23}$.

Instrumental methods. The methods used were essentially the same as in our earlier work ${ }^{11,13,15,16}$. UV - visible spectra were recorded on an HP 8453 spectrophotometer. ${ }^{1} \mathrm{H}$ NMR spectra were recorded on a $400 \mathrm{MHz}$ Bruker Avance III HD spectrometer equipped with a $5 \mathrm{~mm} \mathrm{BB} / 1 \mathrm{H} \mathrm{SmartProbe}$ in $\mathrm{CDCl}_{3}$ and referenced to residual $\mathrm{CHCl}_{3} 7.26 \mathrm{ppm}, \mathrm{C}_{6} \mathrm{D}_{6}$ and referenced to residual $\mathrm{C}_{6} \mathrm{H}_{6} 7.16 \mathrm{ppm}, \mathrm{C}_{3} \mathrm{D}_{6} \mathrm{O}$ and referenced to residual $\mathrm{C}_{3} \mathrm{H}_{6} \mathrm{O} 2.05 \mathrm{ppm}$ or $\mathrm{CD}_{3} \mathrm{OD}$ and referenced to residual $\mathrm{CH}_{3} \mathrm{OH} 3.31 \mathrm{ppm}$. High-resolution electrospray-ionization (HR-ESI) mass spectra were recorded from methanolic solution on an LTQ Orbitrap XL spectrometer.

Cyclic voltammetry was performed at $298 \mathrm{~K}$ using an EG\&G model 263 A potentiostat with a three-electrode system, comprising a glassy carbon working electrode, a platinum wire counter electrode, and a saturated calomel reference electrode (SCE), in $\mathrm{CH}_{2} \mathrm{Cl}_{2}$ (distilled from $\mathrm{CaH}_{2}$ ) as solvent (as in earlier work ${ }^{11,13,15,16}$ ). The reference electrode was separated from the bulk solution by a fritted-glass bridge filled with the electrolyte solution. The electrolyte solution was purged with argon for several minutes, and electrochemical measurements were conducted under an argon blanket. All potentials are referenced to the SCE.

The phosphorescence of the $\operatorname{Ir}(\mathrm{III})$ corroles was studied on a Fluorolog 3 fluorescence spectrometer from Horiba (Japan) equipped with an NIR-sensitive photomultiplier R2658 from Hamamatsu (Japan). The spectra were corrected for the sensitivity of the photomultiplier and smoothing processing (adjusting averaging function) was applied to eliminate noise due to low signals. For measurements at room temperature, dye solutions in a sealable quartz cell (Hellma Analytics, Mülheim, Germany) were deoxygenated by bubbling nitrogen (purity 99.9999\%, Linde gas, Austria) for $15 \mathrm{~min}$. Measurements at $77 \mathrm{~K}$ were conducted in toluene:tetrahydrofuran $(4: 6 \mathrm{v} / \mathrm{v})$ or ethanol/methanol $(4: 1 \mathrm{v} / \mathrm{v})$ frozen glass using accessories for deep-temperature measurements from Horiba. Luminescence decay times were measured on the Fluorolog 3 spectrometer equipped with a DeltaHub module (Horiba Scientific) controlling a SpectraLED-460 light source and using DAS-6 Analysis software for data analysis. 
Singlet oxygen generation was studied as previously described ${ }^{7}$. Briefly, a stirred solution containing 9,10-dimethylanthracene $(0.2 \mathrm{mM})$ as a singlet oxygen acceptor and a sensitizer (concentration adjusted to achieve identical absorption for all the sensitizers at $\lambda_{\mathrm{ex}}$ ) was irradiated with light from the xenon lamp of the Fluorolog spectrometer $\left(\lambda_{\mathrm{ex}} 575 \mathrm{~nm}\right)$. The degradation of the acceptor was assessed via measurement of the UV-vis spectra.

General procedure for the synthesis of $\operatorname{Ir}[\mathrm{T} p X P C] \mathrm{L}_{2}\left(\mathrm{X}=\mathrm{OMe}, \mathrm{CH}_{3}, \mathrm{H}, \mathrm{CF}_{3}\right.$, L=tma, py, dmap, 4pa, isoq). The iridium complexes were prepared according to a previously reported procedure ${ }^{10}$ with slight modifications. Bis(1,5-cyclooctadiene)diiridium(I) dichloride (Merck, 2 eq) and potassium carbonate (10 eq.) were dissolved in a solution of the free-base corrole $(\sim 0.1 \mathrm{mmol}, 1 \mathrm{eq})$ in anhydrous tetrahydrofuran $(150 \mathrm{~mL})$. After degassing with argon for a few minutes, the solution was brought to reflux under argon. After 1.5 h, a reagent corresponding to the axial ligand ( $15 \mathrm{eq}$ ) was added all at once and the solution was left to reach room temperature $(1 \mathrm{~h})$. For $\mathrm{L}=$ tma, the reagent used was trimethylamine $N$-oxide; in the other cases, the unmodifed ligand was used. The reaction mixture was then rotary-evaporated to dryness. Unless otherwise mentioned, the residue was dissolved in a small amount of dichloromethane and subjected to column chromatography (silica, 1:1 $\mathrm{CH}_{2} \mathrm{Cl}_{2}$ :hexanes) followed by preparative thin-layer chromatography (PTLC, silica, 1:1 $\mathrm{CH}_{2} \mathrm{Cl}_{2}$ :pentane). Additional details of purification and characterization for each new compound are given below. As in earlier studies of Ir corroles ${ }^{5,10}$, accurate elemental analyses could not be consistently obtained; proof of composition and purity was accordingly obtained via thin-layer chromatography, clean high-resolution mass spectra that matched theoretical simulations, and, in three cases, single-crystal X-ray structure determinations.

$\operatorname{Ir}[T P C] t_{m a}$. PTLC afforded the product as a dichroic purple-green solid. Yield $37.5 \mathrm{mg}(30 \%)$. UV-vis $\left(\mathrm{CH}_{2} \mathrm{Cl}_{2}\right) \lambda_{\max }(\mathrm{nm})\left[\epsilon \times 10^{-4}\left(\mathrm{M}^{-1} \mathrm{~cm}^{-1}\right)\right]: 384(3.65, \mathrm{sh}), 416(5.58), 468(1.59, \mathrm{sh}), 596(2.67) .{ }^{1} \mathrm{H} \mathrm{NMR}(400 \mathrm{MHz}$, acetone- $\left.d_{6}, \delta\right): 8.88(\mathrm{~d}, J=4.1 \mathrm{~Hz}, 2 \mathrm{H}, \beta-\mathrm{H}), 8.62(\mathrm{~d}, J=4.7 \mathrm{~Hz}, 2 \mathrm{H}, \beta-\mathrm{H}), 8.39(\mathrm{~d}, J=4.8 \mathrm{~Hz}, 2 \mathrm{H}, \beta-\mathrm{H}), 8.24-8.19$ $(\mathrm{m}, 4 \mathrm{H}, 5,15 o-\mathrm{Ph}), 8.15-8.11(\mathrm{~m}, 2 \mathrm{H}, 10 o-\mathrm{Ph}), 8.01(\mathrm{~s}, 2 \mathrm{H}, \beta-\mathrm{H}), 7.78(\mathrm{dt}, J=14.9,7.5 \mathrm{~Hz}, 6 \mathrm{H}, 5,10,15 \mathrm{~m}-\mathrm{Ph})$,

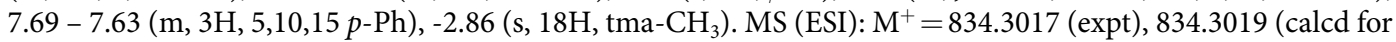
$\mathrm{IrC}_{43} \mathrm{H}_{41} \mathrm{~N}_{6}$ ).

$\operatorname{Ir}[T P C] p y_{2}$. PTLC afforded the product as a dichroic purple-green solid. Yield $83.4 \mathrm{mg}(63.6 \%)$. UV-vis $\left(\mathrm{CH}_{2} \mathrm{Cl}_{2}\right) \lambda_{\max }(\mathrm{nm})\left[\epsilon \times 10^{-4}\left(\mathrm{M}^{-1} \mathrm{~cm}^{-1}\right)\right]: 414(5.30), 459(2.66, \mathrm{sh}), 562(0.86, \mathrm{sh}), 602(3.37) .{ }^{1} \mathrm{H} \mathrm{NMR}(400 \mathrm{MHz}$, acetone- $\left.d_{6}, \delta\right): 8.82-8.78(\mathrm{~m}, 2 \mathrm{H}, \beta-\mathrm{H}), 8.62(\mathrm{dd}, J=4.8,1.1 \mathrm{~Hz}, 2 \mathrm{H}, \beta-\mathrm{H}), 8.38(\mathrm{~d}, J=4.7 \mathrm{~Hz}, 2 \mathrm{H}, \beta-\mathrm{H}), 8.28-$ $8.22(\mathrm{~m}, 4 \mathrm{H}, 5,15 o-\mathrm{Ph}), 8.17(\mathrm{~d}, J=4.1 \mathrm{~Hz}, 2 \mathrm{H}, \beta-\mathrm{H}), 8.05-8.00(\mathrm{~m}, 2 \mathrm{H}, 10 o-\mathrm{Ph}), 7.77(\mathrm{dd}, J=8.3,6.8 \mathrm{~Hz}, 4 \mathrm{H}$, $5,15 \mathrm{~m}-\mathrm{Ph}), 7.70-7.59(\mathrm{~m}, 5 \mathrm{H}, 5,15 p-\mathrm{Ph}$ and 10 p, $m$ - $\mathrm{Ph}), 6.30(\mathrm{tt}, J=7.6,1.5 \mathrm{~Hz}, 2 \mathrm{H}, p-\mathrm{py}), 5.42-5.33(\mathrm{~m}, 4 \mathrm{H}$, $m$-py), 1.85 (dt, $J=5.4,1.5 \mathrm{~Hz}, 4 \mathrm{H}, o$-py). MS (ESI): $\mathrm{M}^{+}=874.2403$ (expt), 874.2393 (calcd for $\operatorname{IrC}_{47} \mathrm{H}_{33} \mathrm{~N}_{6}$ ).

$\operatorname{Ir}[\mathrm{TpMePC}]$ tma ${ }_{2}$. PTLC with 1:2 $\mathrm{CH}_{2} \mathrm{Cl}_{2}$ :pentane afforded the product as a bright green solid. Yield $75.7 \mathrm{mg}$ (49.6\%). UV-vis $\left(\mathrm{CH}_{2} \mathrm{Cl}_{2}\right) \lambda_{\max }(\mathrm{nm})\left[\epsilon \times 10^{-4}\left(\mathrm{M}^{-1} \mathrm{~cm}^{-1}\right)\right]: 384(3.28, \mathrm{sh}), 417(4.88), 468(1.54, \mathrm{sh}), 598(2.36) .{ }^{1} \mathrm{H}$ NMR (400 MHz, chloroform- $d, \delta): 8.88-8.82(\mathrm{~m}, 2 \mathrm{H}, \beta-\mathrm{H}), 8.66(\mathrm{~d}, J=4.7 \mathrm{~Hz}, 2 \mathrm{H}, \beta-\mathrm{H}), 8.39(\mathrm{~d}, J=4.6 \mathrm{~Hz}, 2 \mathrm{H}$, $\beta-\mathrm{H}), 8.03(\mathrm{dd}, J=47.5,7.5 \mathrm{~Hz}, 8 \mathrm{H} 5,10,15 o-\mathrm{Ph}+\beta-\mathrm{H}, 8 \mathrm{H}), 7.57(\mathrm{dd}, J=14.0,7.6 \mathrm{~Hz}, 6 \mathrm{H}, 5,10,15 m-\mathrm{Ph}), 1.28$ (s, $\left.9 \mathrm{H}, \mathrm{Ph} p-\mathrm{CH}_{3}\right),-2.88\left(\mathrm{~s}, 18 \mathrm{H}\right.$, tma-CH $\mathrm{CH}_{3}$ ). MS (ESI): $\mathrm{M}^{+}=876.3488$ (expt), $876.3489\left(\right.$ calcd for $\operatorname{IrC}_{46} \mathrm{H}_{47} \mathrm{~N}_{6}$ ).

$\operatorname{Ir}\left[\mathrm{T} p \mathrm{MePC}_{\mathrm{N}} \mathrm{y}_{2}\right.$. PTLC afforded the product as a dichroic purple-green solid. Yield $36 \mathrm{mg}(30.1 \%)$. UV-vis $\left(\mathrm{CH}_{2} \mathrm{Cl}_{2}\right) \lambda_{\max }(\mathrm{nm})\left[\epsilon \times 10^{-4}\left(\mathrm{M}^{-1} \mathrm{~cm}^{-1}\right)\right]: 417(6.40), 460(2.75, \mathrm{sh}), 562(0.98, \mathrm{sh}), 603(3.49) .{ }^{1} \mathrm{H} \mathrm{NMR}(400 \mathrm{MHz}$, benzene- $\left.d_{6}, \delta\right): 9.14(\mathrm{dd}, J=4.5,3.0 \mathrm{~Hz}, 4 \mathrm{H}, \beta-\mathrm{H}), 8.97(\mathrm{~d}, J=4.8 \mathrm{~Hz}, 2 \mathrm{H}, \beta-\mathrm{H}), 8.80(\mathrm{~d}, J=4.2 \mathrm{~Hz}, 2 \mathrm{H}, \beta-\mathrm{H}), 8.46$ $-8.41(\mathrm{~m}, 4 \mathrm{H}, 5,15 o-\mathrm{Ph}), 8.30(\mathrm{~d}, J=7.9 \mathrm{~Hz}, 2 \mathrm{H}, 10 o-\mathrm{Ph}), 7.42(\mathrm{~d}, J=7.7 \mathrm{~Hz}, 4 \mathrm{H}, 5,15 \mathrm{~m}-\mathrm{Ph}), 7.37(\mathrm{~d}, J=8.0 \mathrm{~Hz}$, $2 \mathrm{H}, 10 m-\mathrm{Ph}), 4.79$ (t, $J=7.6 \mathrm{~Hz}, 2 \mathrm{H}, p$-py), $4.17-4.11$ (m, $4 \mathrm{H}, m-\mathrm{py}), 2.42\left(\mathrm{~d}, J=4.2 \mathrm{~Hz}, 9 \mathrm{H}, \mathrm{Ph}-p-\mathrm{CH}_{3}\right), 2.06$ $\left(\mathrm{dt}, J=5.3,1.5 \mathrm{~Hz}, 4 \mathrm{H}, o\right.$-py). MS (ESI): $\mathrm{M}^{+}=916.2868$ (expt), 916.2863 (calcd for $\operatorname{IrC}_{50} \mathrm{H}_{39} \mathrm{~N}_{6}$ ).

$\operatorname{Ir}[\mathrm{T} p \mathrm{OMePC}] \mathrm{tma}_{2}$. During initial column chromatography on silica, the eluent was gradually changed from 1:1 $\mathrm{CH}_{2} \mathrm{Cl}_{2}$ :hexanes to $\mathrm{CH}_{2} \mathrm{Cl}_{2}$, and finally to 9:1 $\mathrm{CH}_{2} \mathrm{Cl}_{2}$ :EtOAc. PTLC with 4:1 EtOAc: $\mathrm{CH}_{2} \mathrm{Cl}_{2}$ then afforded the product as a bright green solid. Yield $35.2 \mathrm{mg}(29.2 \%)$. UV-vis $\left(\mathrm{CH}_{2} \mathrm{Cl}_{2}\right) \lambda_{\max }(\mathrm{nm})\left[\epsilon \mathrm{x} 10^{-4}\left(\mathrm{M}^{-1} \mathrm{~cm}^{-1}\right)\right]: 384(0.74$, sh), 417 (1.05), 468 (0.36, sh), 600 (0.48). ${ }^{1} \mathrm{H}$ NMR (400 MHz, chloroform- $\left.d, \delta\right): 8.89(\mathrm{~d}, J=3.8 \mathrm{~Hz}, 2 \mathrm{H}, \beta-\mathrm{H}), 8.68$ $(\mathrm{d}, J=4.7 \mathrm{~Hz}, 2 \mathrm{H}, \beta-\mathrm{H}), 8.32(\mathrm{~d}, J=4.6 \mathrm{~Hz}, 2 \mathrm{H}, \beta-\mathrm{H}), 8.06(\mathrm{~d}, J=8.0 \mathrm{~Hz}, 4 \mathrm{H}, 5,15 o-\mathrm{Ph}), 7.92(\mathrm{~d}, J=7.9 \mathrm{~Hz}, 2 \mathrm{H}, 10$ $o$ - $\mathrm{Ph}$ ), $7.83(\mathrm{~s}, 2 \mathrm{H}, \beta-\mathrm{H}), 7.33$ (dd, $J=11.7,8.2 \mathrm{~Hz}, 6 \mathrm{H}, 5,10,15 \mathrm{~m}-\mathrm{Ph}), 4.09$ (d, $\left.J=3.6 \mathrm{~Hz}, 9 \mathrm{H}, \mathrm{Ph} p-\mathrm{OCH}_{3}\right),-2.86$ (s, $18 \mathrm{H}$, tma- $\mathrm{CH}_{3}$ ). MS (ESI): $\mathrm{M}^{+}=924.3336$ (expt), 924.3336 (calcd for $\operatorname{IrC}_{46} \mathrm{H}_{47} \mathrm{O}_{3} \mathrm{~N}_{6}$ ).

$\operatorname{Ir}[\mathrm{TpOMePC}] \mathrm{Py}_{2}$. $\quad$ PTLC afforded the product as a bright green solid. Yield $31.2 \mathrm{mg}(24.5 \%)$. UV-vis $\left(\mathrm{CH}_{2} \mathrm{Cl}_{2}\right) \lambda_{\max }(\mathrm{nm})\left[\epsilon \times 10^{-4}\left(\mathrm{M}^{-1} \mathrm{~cm}^{-1}\right)\right]: 416(3.98), 458(2.14, \mathrm{sh}), 563(0.77, \mathrm{sh}), 605(2.36) .{ }^{1} \mathrm{H} \mathrm{NMR}(400 \mathrm{MHz}$, benzene- $\left.d_{6}, \delta\right): 9.19-9.15(\mathrm{~m}, 4 \mathrm{H}, 2 \beta-\mathrm{H}), 8.98(\mathrm{~d}, J=4.9 \mathrm{~Hz}, 2 \mathrm{H}, \beta-\mathrm{H}), 8.76(\mathrm{~s}, 2 \mathrm{H}, \beta-\mathrm{H}), 8.42(\mathrm{~d}, J=8.0 \mathrm{~Hz}, 4 \mathrm{H}$, $5,15 o-\mathrm{Ph}), 8.08(\mathrm{~d}, J=8.5 \mathrm{~Hz}, 2 \mathrm{H}, 10 o-\mathrm{Ph}), 7.20(\mathrm{~d}, J=8.8 \mathrm{~Hz}, 4 \mathrm{H}, 5,15 \mathrm{~m}-\mathrm{Ph}), 7.11-7.07(\mathrm{~m}, 2 \mathrm{H}, 10 \mathrm{~m}-\mathrm{Ph})$, 4.81 (ddd, $J=7.7,6.2,1.5 \mathrm{~Hz}, 2 \mathrm{H}, p$-py), $4.20-4.16$ (m, 4H, $m$-py), 3.55 (d, J=2.0 Hz, 9H, Ph $p-\mathrm{OCH}_{3}$ ), $2.11-$ 2.07 (m, 4H, o-py). MS (ESI): $\mathrm{M}^{+}=964.2738$ (expt), $964.2710\left(\right.$ calcd for $\operatorname{IrC}_{50} \mathrm{H}_{39} \mathrm{O}_{3} \mathrm{~N}_{6}$ ).

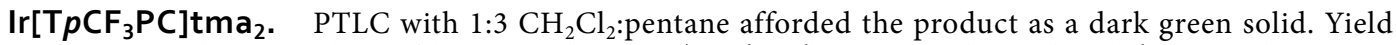
$14.7 \mathrm{mg}(11.8 \%)$. UV-vis $\left(\mathrm{CH}_{2} \mathrm{Cl}_{2}\right) \lambda_{\max }(\mathrm{nm})\left[\epsilon \mathrm{x}^{-4}\left(\mathrm{M}^{-1} \mathrm{~cm}^{-1}\right)\right]: 418(2.13), 595(0.68) .{ }^{1} \mathrm{H} \mathrm{NMR}(400 \mathrm{MHz}$, chloroform- $d$, $\delta): 8.89(\mathrm{~d}, J=4.2 \mathrm{~Hz}, 2 \mathrm{H}, \beta-\mathrm{H}), 8.64(\mathrm{~d}, J=4.8 \mathrm{~Hz}, 2 \mathrm{H}, \beta-\mathrm{H}), 8.48(\mathrm{~d}, J=4.8 \mathrm{~Hz}, 2 \mathrm{H}, \beta-\mathrm{H}), 8.38$ $(\mathrm{d}, J=7.8 \mathrm{~Hz}, 4 \mathrm{H}, 5,15 o-\mathrm{Ph}), 8.29(\mathrm{~d}, J=7.8 \mathrm{~Hz}, 2 \mathrm{H}, 10 o-\mathrm{Ph}), 8.20(\mathrm{~d}, J=4.2 \mathrm{~Hz}, 2 \mathrm{H}, \beta-\mathrm{H}), 8.01(\mathrm{~d}, J=7.9 \mathrm{~Hz}$, $4 \mathrm{H}, 5,15 \mathrm{~m}-\mathrm{Ph}), 7.98(\mathrm{~d}, J=7.9 \mathrm{~Hz}, 2 \mathrm{H}, 10 o-\mathrm{Ph}),-2.93\left(\mathrm{~s}, 18 \mathrm{H}, \mathrm{tma}-\mathrm{CH}_{3}\right) . \mathrm{MS}(\mathrm{ESI}): \mathrm{M}^{+}=1038.2654$ (expt), 1038.2641 (calcd for $\mathrm{IrC}_{46} \mathrm{H}_{38} \mathrm{~F}_{9} \mathrm{~N}_{6}$ ). 
$\operatorname{Ir}\left[\mathrm{T} p \mathrm{CF}_{3} \mathrm{PC}\right] \mathrm{py} \mathbf{2}_{2}$. PTLC with 1:2 $\mathrm{CH}_{2} \mathrm{Cl}_{2}$ :pentane afforded the product as a dark green solid. Yield $16.3 \mathrm{mg}$ (13.7\%). UV-vis $\left(\mathrm{CH}_{2} \mathrm{Cl}_{2}\right) \lambda_{\max }(\mathrm{nm})\left[\epsilon \mathrm{x} 10^{-4}\left(\mathrm{M}^{-1} \mathrm{~cm}^{-1}\right)\right]: 416$ (3.86), 602 (1.48). ${ }^{1} \mathrm{H}$ NMR (400 MHz, benzene- $d_{6}$,

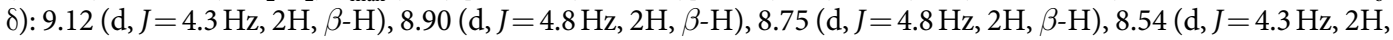
$\beta-\mathrm{H}), 8.30(\mathrm{~d}, J=8.0 \mathrm{~Hz}, 4 \mathrm{H}, 5,15 o-\mathrm{Ph}), 8.23(\mathrm{~d}, J=7.9 \mathrm{~Hz}, 2 \mathrm{H}, 10 o-\mathrm{Ph}), 7.76(\mathrm{dd}, J=8.1,6.6 \mathrm{~Hz}, 6 \mathrm{H}, 5,10,15$ $m$-Ph), $4.84(\mathrm{tt}, J=7.7,1.5 \mathrm{~Hz}, 2 \mathrm{H}, p$-py), $4.23-4.17$ (m, $4 \mathrm{H}, m$-py), 1.86 (dt, $J=5.6,1.5 \mathrm{~Hz}, 4 \mathrm{H}, o$-py). MS (ESI): $\mathrm{M}^{+}=1078.2032$ (expt), 1078.2015 (calcd for $\operatorname{IrC}_{50} \mathrm{H}_{30} \mathrm{~F}_{9} \mathrm{~N}_{6}$ ).

$\operatorname{Ir}\left[\mathrm{T}_{p} \mathrm{CF}_{3} \mathrm{PC}\right] \mathrm{dmap}_{2}$. Initial column chromatography was carried out on neutral alumina with $1: 1$ $\mathrm{CH}_{2} \mathrm{Cl}_{2}$ :hexanes as eluent. PTLC on alumina with the same eluent afforded the product as a green solid. Yield $31.7 \mathrm{mg}(18.1 \%)$. UV-vis $\left(\mathrm{CH}_{2} \mathrm{Cl}_{2}\right) \lambda_{\max }(\mathrm{nm})\left[\epsilon \times 10^{-4}\left(\mathrm{M}^{-1} \mathrm{~cm}^{-1}\right)\right]: 418(1.79), 606(0.48) .{ }^{1} \mathrm{H} \mathrm{NMR}(400 \mathrm{MHz}$, benzene- $\left.d_{6}, \delta\right): 9.20(\mathrm{~d}, J=4.2 \mathrm{~Hz}, 2 \mathrm{H}, \beta-\mathrm{H}), 8.99(\mathrm{~d}, J=4.8 \mathrm{~Hz}, 2 \mathrm{H}, \beta-\mathrm{H}), 8.86(\mathrm{~d}, J=4.8 \mathrm{~Hz}, 2 \mathrm{H}, \beta-\mathrm{H}), 8.60$ $(\mathrm{d}, J=4.2 \mathrm{~Hz}, 2 \mathrm{H}, \beta-\mathrm{H}), 8.45(\mathrm{~d}, J=7.9 \mathrm{~Hz}, 4 \mathrm{H}, 5,15 o-\mathrm{Ph}), 8.40(\mathrm{~d}, J=7.9 \mathrm{~Hz}, 2 \mathrm{H}, 10 o-\mathrm{Ph}), 7.77(\mathrm{dd}, J=8.3$, $2.1 \mathrm{~Hz}, 6 \mathrm{H}, 5,10,15 \mathrm{~m}-\mathrm{Ph}), 3.57-3.52\left(\mathrm{~m}, 4 \mathrm{H}, \mathrm{m}\right.$-py), $1.76-1.69(\mathrm{~m}, 4 \mathrm{H}, o-\mathrm{Ph}), 1.07\left(\mathrm{~s}, 6 \mathrm{H}, \mathrm{N}-\mathrm{CH}_{3}\right), 1.00(\mathrm{~s}, 6 \mathrm{H}$, $\mathrm{N}-\mathrm{CH}_{3}$ ). MS (ESI): $\mathrm{M}^{+}=1164.2855$ (expt), 1164.2860 (calcd for $\operatorname{IrC}_{54} \mathrm{H}_{40} \mathrm{~F}_{9} \mathrm{~N}_{8}$ ).

$\operatorname{Ir}\left[\mathrm{T}_{\mathrm{C}} \mathrm{CF}_{3} \mathrm{PC}\right](\mathbf{4 p a})_{2}$. Initial column chromatography was carried out on neutral alumina with 1:1 $\mathrm{CH}_{2} \mathrm{Cl}_{2}$ :EtOAc. PTLC on alumina with the same eluent afforded the product as a green solid. Yield $29.6 \mathrm{mg}$ (40.1\%). UV-vis $\left(\mathrm{CH}_{2} \mathrm{Cl}_{2}\right) \lambda_{\max }(\mathrm{nm})\left[\epsilon \times 10^{-4}\left(\mathrm{M}^{-1} \mathrm{~cm}^{-1}\right)\right]: 414(1.71), 602(0.94) .{ }^{1} \mathrm{H}$ NMR $\left(400 \mathrm{MHz}\right.$, methanol- $d_{4}$, $\delta): 8.88(\mathrm{~d}, J=4.2 \mathrm{~Hz}, 2 \mathrm{H}, \beta-\mathrm{H}), 8.61(\mathrm{~d}, J=4.8 \mathrm{~Hz}, 2 \mathrm{H}, \beta-\mathrm{H}), 8.43-8.41(\mathrm{~m}, 6 \mathrm{H}, \beta-\mathrm{H}+5,15 o-\mathrm{Ph}), 8.28(\mathrm{~d}$, $J=8.0 \mathrm{~Hz}, 2 \mathrm{H}, 10 o-\mathrm{Ph}), 8.24(\mathrm{~d}, J=4.3 \mathrm{~Hz}, 2 \mathrm{H}, \beta-\mathrm{H}), 8.08-8.03(\mathrm{~m}, 4 \mathrm{H}, 5,15 \mathrm{~m}-\mathrm{Ph}), 7.99(\mathrm{~d}, J=7.9 \mathrm{~Hz}$, $2 \mathrm{H}, 10 m-\mathrm{Ph}), 5.61$ (d, $J=7.1 \mathrm{~Hz}, 4 \mathrm{H}, m$-py), 1.75 (d, $J=7.0 \mathrm{~Hz}, 4 \mathrm{H}, o$-py). MS (ESI): $\mathrm{M}^{-}=1165.1729$ (expt), 1165.1745 (calcd for $\mathrm{IrC}_{52} \mathrm{H}_{29} \mathrm{~F}_{9} \mathrm{~N}_{6} \mathrm{O}_{4}$ ).

$\operatorname{Ir}[\mathrm{TpCF3PC}] \mathbf{i s o q}_{2}$. Initial column chromatography was carried out on silica with $1: 3 \mathrm{CH}_{2} \mathrm{Cl}_{2}$ :hexanes as eluent. PTLC on silica with the same eluent afforded the product as a green solid. Yield $12.1 \mathrm{mg}(7.9 \%)$. UV-vis $\left(\mathrm{CH}_{2} \mathrm{Cl}_{2}\right) \lambda_{\max }(\mathrm{nm})\left[\mathrm{\epsilon} \times 10^{-4}\left(\mathrm{M}^{-1} \mathrm{~cm}^{-1}\right)\right]: 417$ (1.82), 603 (1.02). ${ }^{1} \mathrm{H}$ NMR (400 MHz, chloroform- $\left.d, \delta\right): 8.88(\mathrm{~d}$, $J=4.2 \mathrm{~Hz}, 2 \mathrm{H}, \beta-\mathrm{H}), 8.69(\mathrm{~d}, J=4.8 \mathrm{~Hz}, 2 \mathrm{H}, \beta-\mathrm{H}), 8.46(\mathrm{~d}, J=4.7 \mathrm{~Hz}, 2 \mathrm{H}, \beta-\mathrm{H}), 8.43(\mathrm{~d}, J=7.9 \mathrm{~Hz}, 4 \mathrm{H}, 5,15$ $o-\mathrm{Ph}), 8.29(\mathrm{~s}, 2 \mathrm{H}, \beta-\mathrm{H}), 8.24(\mathrm{~d}, J=7.9 \mathrm{~Hz}, 2 \mathrm{H}, 10 o-\mathrm{Ph}), 8.05-7.99(\mathrm{~m}, 4 \mathrm{H}, 5,15 \mathrm{~m}-\mathrm{Ph}), 7.93(\mathrm{~d}, J=7.9 \mathrm{~Hz}, 2 \mathrm{H}$, $10 \mathrm{~m}$ - $\mathrm{Ph}$ ), 7.07 (ddd, $J=8.2,6.9,1.2 \mathrm{~Hz}, 2 \mathrm{H}$, isoquinoline $\mathrm{C} 7$ ), 6.93 (ddd, $J=8.2,6.9,1.1 \mathrm{~Hz}, 2 \mathrm{H}$, isoquinoline C6), $6.76-6.72(\mathrm{~m}, 2 \mathrm{H}$, isoquinoline $\mathrm{C} 8), 6.40(\mathrm{~d}, J=8.4 \mathrm{~Hz}, 2 \mathrm{H}$, isoquinoline $\mathrm{C} 5), 5.58-5.54(\mathrm{~m}, 2 \mathrm{H}$, isoquinoline C4), 2.36 (s, $2 \mathrm{H}$, isoquinoline $\mathrm{C} 1), 1.68\left(\mathrm{~d}, J=6.9 \mathrm{~Hz}, 2 \mathrm{H}\right.$, isoquinoline C3). MS (ESI): $\mathrm{M}^{-}=1178.2351$ (expt), 1178.2329 (calcd for $\operatorname{IrC}_{58} \mathrm{H}_{34} \mathrm{~F}_{9} \mathrm{~N}_{6}$ ).

X-ray structure determinations. X-ray data for $\operatorname{Ir}[\mathrm{TPC}] \mathrm{tma}_{2}, \operatorname{Ir}[\mathrm{T} p \mathrm{MePC}] \mathrm{tma}_{2}$, and $\operatorname{Ir}\left[\mathrm{T} p \mathrm{CF} \mathrm{PC}_{3} \mathrm{PC}\right.$ $\mathrm{py}_{2}$ were collected on beamline 11.3.1 at the Advanced Light Source, Lawrence Berkeley National Laboratory.

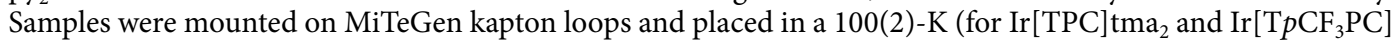
$\mathrm{py}_{2}$ ) or $150(2)-\mathrm{K}$ (for $\operatorname{Ir}\left[\mathrm{T} p \mathrm{CF}_{3} \mathrm{PC}\right] \mathrm{py}_{2}$ ) nitrogen cold stream provided by an Oxford Cryostream 800 Plus low-temperature apparatus on the goniometer head of a Bruker D8 diffractometer equipped with a PHOTON100 CMOS detector operating in shutterless mode. Diffraction data were collected using synchrotron radiation monochromated using silicon(111) to a wavelength of 0.7293 (1) $\AA$ (for $\operatorname{Ir}[\mathrm{T} p \mathrm{MePC}] \mathrm{tma}_{2}$ ) or 0.7749 (1) $\AA$ (for Ir[TPC] $\mathrm{tma}_{2}$ and $\left.\operatorname{Ir}\left[\mathrm{T} p \mathrm{CF}_{3} \mathrm{PC}\right] \mathrm{py}_{2}\right)$. An approximate full-sphere of data was collected using a combination of $\varphi$ and $\omega$ scans with scan speeds of one second per degree for the $\varphi$ scans and one and three seconds per degree for the $\omega$ scans at $2 \theta=0^{\circ}$ and $-45^{\circ}$, respectively. The structures were solved by intrinsic phasing (SHELXT ${ }^{24}$ ) and refined by full-matrix least-squares on $F^{2}$ (SHELXL-2014 ${ }^{25}$ ). All non-hydrogen atoms were refined anisotropically. Hydrogen atoms were geometrically calculated and refined as riding atoms. Additional crystallographic information has been summarized in Table 2 .

Received: 6 February 2020; Accepted: 16 April 2020;

Published online: 05 May 2020

\section{References}

1. Ghosh, A. Electronic Structure of Corrole Derivatives: Insights from Molecular Structures, Spectroscopy, Electrochemistry, and Quantum Chemical Calculations. Chem. Rev. 117, 3798-3881 (2017).

2. Teo, R. D., Hwang, J. Y., Termini, J., Gross, Z. \& Gray, H. B. Fighting Cancer with Corroles. Chem. Rev. 117, 2711-2729 (2017).

3. Mahammed, A. \& Gross, Z. Corroles as triplet photosensitizers. Coord. Chem. Rev. 379, 121-132 (2019).

4. Palmer, J. H., Durrell, A. C., Gross, Z., Winkler, J. R. \& Gray, H. B. Near-IR Phosphorescence of Iridium(III) Corroles at Ambient Temperature. J. Am. Chem. Soc. 132, 9230-9231 (2010)

5. Sinha, W., Ravotto, L., Ceroni, P. \& Kar, S. NIR-Emissive Iridium(III) Corrole Complexes as Efficient Singlet Oxygen Sensitizers. Dalton Trans. 44, 17767-17773 (2015).

6. Alemayehu, A. B. et al. Gold Tris(carboxyphenyl)corroles as Multifunctional Materials: Room Temperature Near-IR Phosphorescence and Applications to Photodynamic Therapy and Dye-Sensitized Solar Cells. ACS Appl. Mater. Interfaces 8, 18935-18942 (2016).

7. Borisov, S. M., Alemayehu, A. \& Ghosh, A. Osmium-Nitrido Corroles as NIR Indicators for Oxygen Sensors and Triplet Sensitizers for Organic Upconversion and Singlet Oxygen Generation. J. Mater. Chem. C 4, 5822-5828 (2016).

8. Lemon, C. M., Powers, D. C., Brothers, P. J. \& Nocera, D. G. Gold Corroles as Near-IR Phosphors for Oxygen Sensing. Inorg. Chem. 56, 10991-10997 (2017).

9. Alemayehu, A. B., McCormick, L. J., Gagnon, K. J., Borisov, S. M. \& Ghosh, A. ACS Omega 3, 9360-9368 (2018).

10. Palmer, J. H. et al. Iridium Corroles. J. Am. Chem. Soc. 130, 7786-7787 (2008).

11. Alemayehu, A. B. \& Ghosh, A. Gold Corroles. J. Porphyrins Phthalocyanines 15, 106-110 (2011).

12. Rabinovitch, E., Goldberg, I. \& Gross, Z. Gold(I) and Gold(III) Corroles. Chem. Eur. J 17, 12294-12301 (2011)

13. Thomas, K. E., Alemayehu, A. B., Conradie, J., Beavers, C. \& Ghosh, A. Synthesis and Molecular Structure of Gold Triarylcorroles. Inorg. Chem. 50, 12844-12851 (2011). 
14. Thomas, K. E. et al. Ligand Noninnocence in Coinage Metal Corroles: A Silver Knife-Edge. Chem. Eur. J 21, 16839-16847 (2015).

15. Alemayehu, A. B., Gagnon, K. J., Terner, J. \& Ghosh, A. Oxidative Metalation as a Route to Size-Mismatched Macrocyclic Complexes: Osmium Corroles. Angew. Chem. Int. Ed 53, 14411-14414 (2014).

16. Einrem, R. F., Gagnon, K. J., Alemayehu, A. B. \& Ghosh, A. Metal-Ligand Misfits: Facile Access to Rhenium-Oxo Corroles by Oxidative Metalation. Chem. Eur. J 22, 517-520 (2016).

17. Alemayehu, A. B. et al. Platinum Corroles. Chem. Comm 50, 11093-11096 (2014).

18. Gross, E., Ehrenberg, B. \& Johnson, F. M. Singlet Oxygen Generation by Porphyrins and the Kinetics of 9,10-Dimethylanthracene Photosensitization in Liposomes. Photochem. Photobiol. 57, 808-813 (1993).

19. Bonnett, R. Chemical Aspects of Photodynamic Therapy. 1-324 (CRC, 2000).

20. Pandey, R. K., Kessel, D. \& Dougherty, T. J. (eds.) Handbook of photodynamic therapy: updates on recent applications of porphyrinbased compounds. 1-564 (World Scientific, 2016).

21. Nardis, S., Mandoj, F., Stefanelli, M. \& Paolesse, R. Metal complexes of corrole. Coord. Chem. Rev. 388, 360-405 (2019).

22. Gryko, D. T. \& Koszarna, B. Refined methods for the synthesis of meso-substituted $\mathrm{A}_{3}$ - and trans- $\mathrm{A}_{2} \mathrm{~B}$-corroles. Org. Biomol. Chem. 1, 350-357 (2003).

23. Koszarna, B. \& Gryko, D. T. Efficient Synthesis of meso-Substituted Corroles in a $\mathrm{H}_{2} \mathrm{O}-\mathrm{MeOH}$ Mixture. J. Org. Chem. 71, 3707-3717 (2006).

24. Sheldrick, G. M. SHELXT - Integrated Space-Group and Crystal-Structure Determination. Acta Cryst A71, 3-8 (2015).

25. Sheldrick, G. M. Crystal Structure Refinement with SHELXL. Acta Cryst C71, 3-8 (2015).

\section{Acknowledgements}

This work was supported by the Research Council of Norway (grant no. 262229 to AG) and the Arctic Center for Sustainable Energy at UiT - The Arctic University of Norway. The work also used resources of the Advanced Light Source, which is a DOE Office of Science User Facility under contract no. DE-AC02-05CH11231.

\section{Author contributions}

I.K.T. carried out all chemical syntheses, L.M.M. did the X-ray structure determinations, and S.M.B. did the photophysical studies. A.G. planned and coordinated the research. All authors contributed to writing the manuscript text.

\section{Competing interests}

The authors declare no competing interests.

\section{Additional information}

Supplementary information is available for this paper at https://doi.org/10.1038/s41598-020-64389-3.

Correspondence and requests for materials should be addressed to S.M.B. or A.G.

Reprints and permissions information is available at www.nature.com/reprints.

Publisher's note Springer Nature remains neutral with regard to jurisdictional claims in published maps and institutional affiliations.

(c) (i) Open Access This article is licensed under a Creative Commons Attribution 4.0 International License, which permits use, sharing, adaptation, distribution and reproduction in any medium or format, as long as you give appropriate credit to the original author(s) and the source, provide a link to the Creative Commons license, and indicate if changes were made. The images or other third party material in this article are included in the article's Creative Commons license, unless indicated otherwise in a credit line to the material. If material is not included in the article's Creative Commons license and your intended use is not permitted by statutory regulation or exceeds the permitted use, you will need to obtain permission directly from the copyright holder. To view a copy of this license, visit http://creativecommons.org/licenses/by/4.0/.

(c) The Author(s) 2020 